\title{
Vacuum Massage in the Treatment of Scars
}

Peter Moortgat, Jill Meirte, Ulrike Van Daele, Mieke Anthonissen, Tine Vanhullebusch, and Koen Maertens

\section{Contents}

54.1 Working Mechanism of Vacuum Massage in Relation to Pathological Scarring - 477

54.2 The Effects of Vacuum Massage on Scars - 477

54.2.1 General Effects [1, 10-12] - 477

54.2.2 Physical Effects [13-16] - 479

54.2.3 Physiological Effects $[2,10,13,15,17]-479$

54.2.4 Mechanical Effects - 479

54.3 Conclusion -479

Bibliography - 482 


\section{Background}

Vacuum massage is also known as depressomassage, vacuotherapy, or Endermologie $\AA$. It is a non-invasive mechanical massage technique performed with a mechanical device that lifts the skin by means of suction, creates a skin fold, and mobilizes that skin fold [1, 2] as displayed in - Figs. 54.1 and 54.2.

Vacuum massage originates from cupping therapy, a traditional Chinese medicine therapy dating back 2000 years or more. A local suction on the skin is created using heat or mechanical forces in order to create vasodilatation. In the late 1970s, Louis-Paul Guitay suffered from severe skin burns after a car accident. During his rehabilitation, he had to endure hours of manual massages every day. This multi-month process was normal practice for burn victims with extensive scar tissue in the late 1970s. Massage sessions typically lasted 3-4 hours a day and consisted of rigorous routines. The therapist rolled skin and tissue back and forth to regain elasticity. As days grew into weeks, Guitay became dissatisfied with these incessant treatments. They were time-consuming, labor intensive, and he noticed his results varied drastically based on the skills of each individual therapist. Endermologie $\AA$, taken from the French term meaning "through the dermis", was Louis-Paul Guitay's way of standardizing massage therapy to maximize the effect of each treatment. He developed a mechanical device to copy the manual massage techniques by means of negative pressure. This method allowed him to perform the massage in a more consistent way and was less time consuming. From then onward, Endermologie ${ }^{\circledR}$ or vacuum mas-

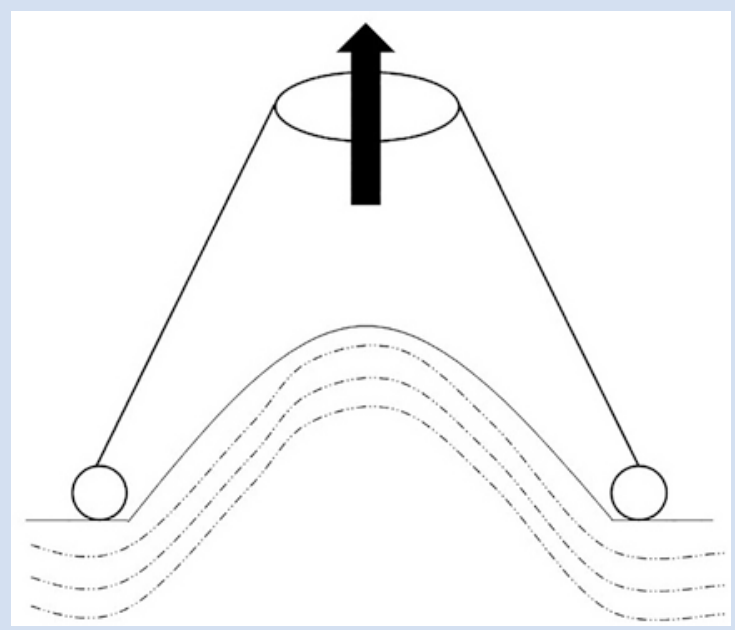

- Fig. 54.1 Vacuum massage creates a skin fold and mobilizes that skin fold sage has been frequently used to treat traumatic or burn scars.

Although vacuum massage was invented to treat burns and scars, very little literature is available on the effects of this intervention. Soon after its development, the device was used extensively in Europe to treat trauma and burn scars [2]. In the course of its use, care providers soon noticed its ability to improve the appearance of cellulite, and consequently most studies mainly focused on lipodystrophy to investigate its working mechanism. The number of studies concerning cellulite is three times higher than those of burns or scars.

The aim of this chapter is to present an overview of the available literature with the physical and physiological effects of vacuum massage. This was done in order to find the underlying working mechanisms of Endermologie ${ }^{\circledR}$ that could benefit the healing of burns and scars. Analyzing the physical and physiological effects of this treatment can increase insights in the influence on the scarring process and may clarify the outcome.

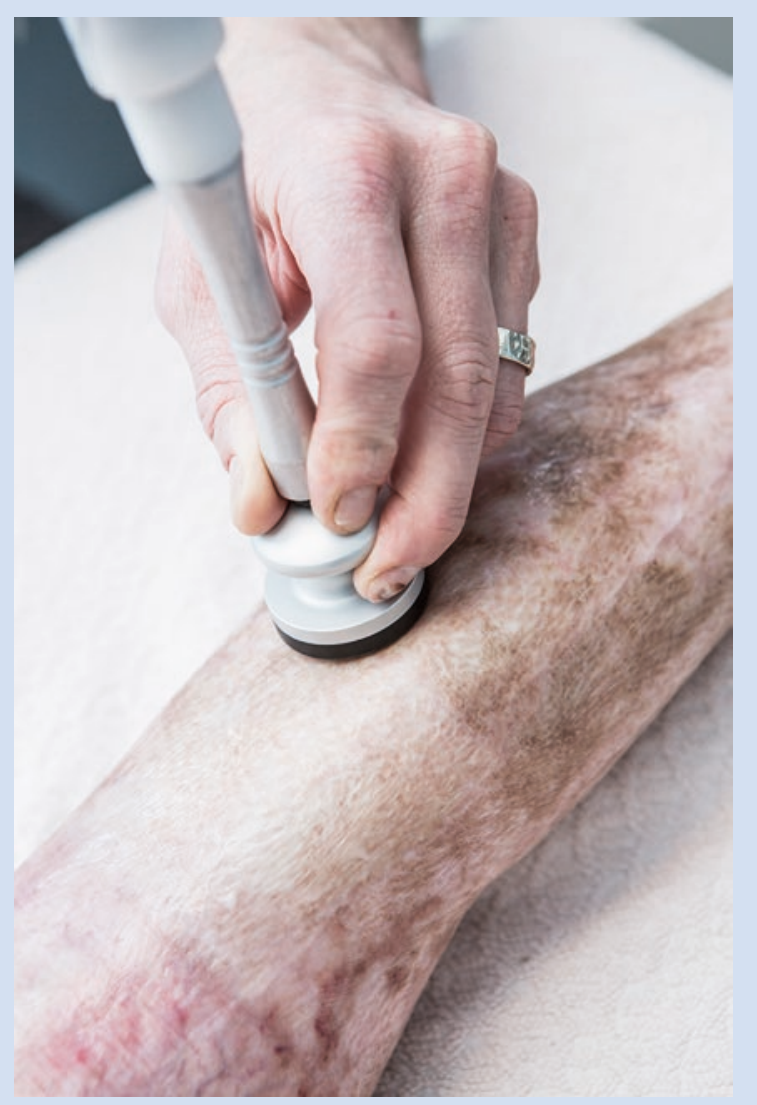

Fig. 54.2 Vacuum massage on scars 


\subsection{Working Mechanism of Vacuum Massage in Relation to Pathological Scarring}

In recent years, there has been an increasing interest in the mechanobiology of scars. The influence of mechanical forces on skin has been examined since 1861 when Langer first reported the existence of lines of tension in cadaver skin [3]. Internal tension in the dermis leads to cell-extracellular matrix (ECM) and cell-cell interactions transferring external mechanical forces into biochemical signals inside the cell [4]. Khan et al. reclaimed the term "mechanotherapy" and presented the current scientific knowledge underpinning how mechanical load may be used therapeutically to stimulate tissue repair and remodeling. It has long been thought that the effectiveness and efficiency of physical therapy would improve if our understanding of the cell biology/biochemistry that participates in mechanics could be improved. Traditional physical therapy focuses primarily on rehabilitation, but recent developments in mechanobiology that illuminated the effects of physical forces on cells and tissues have led to the realization that the old therapy model should be updated. Recent studies showed how mechanotherapies target particular cells, molecules, and tissues. The role of mechanical force in various therapies, including micro-deforming soft tissue techniques, shockwave, vacuum massage, tissue expansion, skin stretching, and tension reduction (tissue targeting) therapies is the subject of numerous ongoing clinical trials [5-7].

All adherent cells including endothelial cells, fibroblasts, and myofibroblasts sense tension originate from the environment. Tension is transmitted via cell-ECM contacts, leading to reorganization of the cytoskeleton and the elicitation of specific signals that modulate gene expression. In skin, alterations of mechanical forces are continuously recognized by cells, and their functions are adapted according to the biological requirements. If mechanical tension is removed, those tissues undergo atrophy, indicating the important role of mechanical signals for maintaining proper functioning of the organism. Obviously, fibroblasts and myofibroblasts are cells implicated in scarring, which is strongly influenced by mechanical tension.

The precise mechanisms by which different cell types transmit mechanical signals are not fully understood. They might involve stretch-activated ion channels, direct interactions between structural and signaling components, or activation of small GTPases. As outlined above, many cooperative interactions exist between integrins and growth factor signaling. In particular, fibroblast to myofibroblast conversion and alpha-smooth muscle actin $(\alpha-S M A)$ expression crucially depend on a combination of mechanical tension and TGF- $\beta$. Thus in scarring, generation of tension can induce myofibroblast formation, causing a self-perpetuating loop. A similar autocrine loop is discussed for the induction of collagen synthesis in fibroblasts by mechanical tension. In this case, TGF- $\beta$ is induced by tension, which in turn activates collagen synthesis via the classic pathways. In addition, fibronectin is induced by the application of cyclic strain to fibroblasts. In parallel, many proteases are downregulated, whereas protease inhibitors are upregulated. As a result of these events, modulation of mechanical tension results in alterations of fibroblast and myofibroblast activity. . Tension directly modifies gene transcription, induces signaling from integrins affecting small GTPases, or induces/inhibits growth factor signaling, which then indirectly affects ECM protein synthesis by fibroblasts/myofibroblasts [8]. By a combination of these mechanisms, mechanical tension induces an activated, contractile fibroblast/myofibroblast phenotype characterized by high levels of synthesis of ECM proteins, low protease activity, and high production of fibrogenic cytokines. Translated into a clinical situation, this means a retractile scar with adhesions between the dermal tissue and the underlying viscera.

The mechanotransduction theories provide possible evidence for several physical non-invasive treatment options. It was suggested that many of the physical scar management methods, including compression therapy, silicone therapy, adhesive tape, and occlusive dressing therapy, are related to mechanotransduction mechanisms. Mechanical compression seems to induce apoptosis and to regulate cytokine release, thus reducing hypertrophic scarring. The effects of mechanical tension on TGF-betal and collagen synthesis leads to the hypothesis that brief, moderate stretch of scar tissue seems to downregulate hypertrophy and retraction of scars and could be the best option for splinting, positioning, and postural stretching [9].

\subsection{The Effects of Vacuum Massage on Scars}

\subsubsection{General Effects [1, 10-12]}

General effects are defined as the effects inherent to the intervention itself or to the individual who performs the treatment. A number of studies mentioned the measured effects were dependent on the number of treatments. The more the treatment, the higher the effect. After this ascertainment, Adcock et al. also discovered that the principal force applied to the tissue during the therapy depended on the particular type of maneuver performed, with the suction and the roller tension being of minor importance. Moreover, they observed a major decrease of tension in thicker tissue.

In four studies performed, the results showed a setback after a follow-up period without treatment, but one study demonstrated the opposite. All these results are shown in $\bullet$ Table 54.1. 
Table 54.1 Basic information available in the literature describing effects of vacuum massage on several skin layers

\begin{tabular}{|c|c|c|c|c|c|c|}
\hline Literature & Etiology & $\begin{array}{l}\text { Study } \\
\text { design }\end{array}$ & $\begin{array}{l}\text { Targeted skin } \\
\text { layer }\end{array}$ & $\begin{array}{l}\text { No. of } \\
\text { patients }\end{array}$ & Assessment & $\begin{array}{l}\text { LESS } \\
\text { score }\end{array}$ \\
\hline $\begin{array}{l}\text { Moortgat et al. } \\
{[16]}\end{array}$ & Burn scars & $\mathrm{CCT}$ & $\begin{array}{l}\text { Epidermis/ } \\
\text { dermis }\end{array}$ & 48 & $\begin{array}{l}\text { POSAS, touch pressure threshold, } \\
\text { DermaLab elasticity }\end{array}$ & 18 \\
\hline $\begin{array}{l}\text { Anthonissen et } \\
\text { al. [15] }\end{array}$ & Burn scars & CCT & $\begin{array}{l}\text { Epidermis/ } \\
\text { dermis }\end{array}$ & 47 & $\begin{array}{l}\text { POSAS, Tristimulus colorimetry, } \\
\text { trans-epidermal water loss }\end{array}$ & 18 \\
\hline Adcock et al. [1] & Pig skin & RCT & $\begin{array}{l}\text { Dermis/ } \\
\text { hypodermis }\end{array}$ & 12 & Histology & 17 \\
\hline Adcock et al. [12] & Pig skin & $\mathrm{RCT}$ & Hypodermis & 4 & Intra-dermal tonometry & 16 \\
\hline Revuz et al. [11] & Aging skin & $\mathrm{CCT}$ & Dermis & 24 & $\begin{array}{l}\text { Subjective assessment of skin laxity and } \\
\text { skin loosening, stereophogrammetry, } \\
\text { cutometer }\end{array}$ & 16 \\
\hline $\begin{array}{l}\text { Moseley et al. } \\
{[18]}\end{array}$ & Scar like & $\mathrm{RCT}$ & $\begin{array}{l}\text { Dermis/ } \\
\text { hypodermis }\end{array}$ & 10 & Likert scale, tonometry & 16 \\
\hline $\begin{array}{l}\text { Lucassen et al. } \\
{[19]}\end{array}$ & Healthy skin & Pre/post & $\begin{array}{l}\text { Dermis/ } \\
\text { hypodermis }\end{array}$ & 19 & High frequency ultrasound & 13 \\
\hline Watson et al. [2] & Healthy skin & $\mathrm{RCT}$ & $\begin{array}{l}\text { Epidermis/ } \\
\text { dermis }\end{array}$ & 5 & $\begin{array}{l}\text { Laser-Doppler imaging, } \\
\text { lymphoscintigraphy, venous flowmetry }\end{array}$ & 13 \\
\hline $\begin{array}{l}\text { Innocenzi et al. } \\
{[14]}\end{array}$ & Lipodystrophy & CCT & $\begin{array}{l}\text { Epidermis/ } \\
\text { dermis }\end{array}$ & 12 & Descriptive histology & 11 \\
\hline $\begin{array}{l}\text { Innocenzi et al. } \\
{[20]}\end{array}$ & Lipodystrophy & $\mathrm{CCT}$ & $\begin{array}{l}\text { Epidermis/ } \\
\text { dermis }\end{array}$ & 15 & Quantitative histology & 10 \\
\hline $\begin{array}{l}\text { Ortonne et al. } \\
{[21]}\end{array}$ & Lipodystrophy & RCT & $\begin{array}{l}\text { Dermis/ } \\
\text { hypodermis }\end{array}$ & 30 & $\begin{array}{l}\text { High frequency ultrasound, fringe } \\
\text { projection, skin fold thickness }\end{array}$ & 13 \\
\hline $\begin{array}{l}\text { Bourgeois et al. } \\
{[13]}\end{array}$ & Scars & $\mathrm{RCT}$ & $\begin{array}{l}\text { Epidermis/ } \\
\text { dermis }\end{array}$ & 20 & $\begin{array}{l}\text { Subjective assessment of pain, itch, } \\
\text { tightness, erythema and skin } \\
\text { smoothening, profilometry }\end{array}$ & 13 \\
\hline $\begin{array}{l}\text { Monteux et al. } \\
{[22]}\end{array}$ & Lipodystrophy & Pre/post & $\begin{array}{l}\text { Dermis/ } \\
\text { hypodermis }\end{array}$ & 9 & Skin fold thickness & 11 \\
\hline $\begin{array}{l}\text { Marques et al. } \\
{[10]}\end{array}$ & Healthy skin & Pre/post & Hypodermis & 12 & Gene profiling, micro-array & 11 \\
\hline Scuderi et al. [23] & Healthy skin & $\mathrm{RCT}$ & $\begin{array}{l}\text { Epidermis/ } \\
\text { dermis }\end{array}$ & 10 & $\begin{array}{l}\text { Subjective assessment of skin } \\
\text { smoothening and skin tone }\end{array}$ & 10 \\
\hline Majani et al. [24] & Scars & Pre/post & $\begin{array}{l}\text { Epidermis/ } \\
\text { dermis }\end{array}$ & 26 & $\begin{array}{l}\text { Subjective assessment of skin } \\
\text { smoothness, pain, tenderness, oedema } \\
\text { and aesthetic improvement, histology }\end{array}$ & 10 \\
\hline $\begin{array}{l}\text { Marquez-Rebollo } \\
\text { et al. [25] }\end{array}$ & Scar like & Pre/post & $\begin{array}{l}\text { Epidermis/ } \\
\text { dermis }\end{array}$ & 70 & Number of indurations & 10 \\
\hline Gavroy et al. [26] & Scars & $\mathrm{CCT}$ & $\begin{array}{l}\text { Details not } \\
\text { available }\end{array}$ & 606 & Test de glissement & 7 \\
\hline $\begin{array}{l}\text { Lattarulo et al. } \\
\text { [27] }\end{array}$ & Healthy skin & Pre/post & $\begin{array}{l}\text { Epidermis/ } \\
\text { dermis }\end{array}$ & 34 & Laser-Doppler imaging, tcpO & 7 \\
\hline Worret et al. [28] & Scar like & Pre/post & Dermis & 10 & $\begin{array}{l}\text { Subjective assessment of pain, color and } \\
\text { elasticity, quality of life, cutometer }\end{array}$ & 7 \\
\hline Delprat et al. [29] & Scars & Pre/post & $\begin{array}{l}\text { Details not } \\
\text { available }\end{array}$ & 132 & Test de glissement & 5 \\
\hline
\end{tabular}

$R C T$ randomized controlled trial, $C C T$ controlled clinical trial, tcp $\mathrm{O}_{2}$ transcutaneous oxygen pressure 


\subsubsection{Physical Effects [13-16]}

An improvement of the tissue hardness and the elasticity of the skin were the two most observed effects. However, most of the studies used subjective methods to quantify these effects. Other reported physical effects were decreased skin fold thickness, decreased face volume, improved skin laxity, increased epidermal thickness, and improved skin roughness. Recent studies have shown that elasticity and redness, measured with subjective and objective assessment tools, were significantly improved after 1 year when the scar was treated for 6 months. The results of one study also revealed that the vacuum massage had minimal value as additive treatment to pressure garments and silicone when it concerned redness. For elasticity, on the other hand, vacuum massage + pressure therapy and silicone seemed to perform better than pressure therapy and silicone alone. The results are set out in - Table 54.2.

\subsubsection{Physiological Effects} $[2,10,13,15,17]$

An improvement in blood perfusion was noticed in four studies. Fibroblast proliferation was enhanced together with an increase in collagen content. Two studies mentioned an improved venous and lymphatic flow together with increased transcutaneous oxygen pressure. Smoothening of the dermo-hypodermal junction and a decreased dermal interstitial space were also observed. One study mentioned altered gene expression profiles in adipose tissue. In another study, a significant decrease of trans-epidermal water loss (TEWL) was found and indicated a recovery of the skin barrier. After correction for baseline and age of scar, there was evidence for lower mean TEWL values in the vacuum massage group, significant after 3 months ( $p=0.006$ ). Humbert et al. investigated the histological effects of vacuum massage and discovered an increased migratory ability of fibroblasts together with increased elastin and hyaluronic acid presence which indicated induced remodeling capacity. The upregulation of MMP-9 suggests degradation of the existing damaged ECM to induce remodeling. These findings were somehow confirmed by the study of
Meirte et al., where an increased dermal thickness together with a decreased dermal density were already noticed in the first 2 hours after a vacuum massage treatment. These results are shown in $\bullet$ Table 54.3.

\subsubsection{Mechanical Effects}

The suction forces generated by vacuum massage could elicit an array of mechanical forces within the tissues, associated with a relaxation of those mechanical forces. Once stress forces on a wound were relieved, apoptosis of myofibroblasts would occur. This finding implies that vacuum massage may release the mechanical stress associated with scar retraction, and thus induce apoptosis. This can be another plausible theory for its mechanism of action to improve the outcome of (burn) scars.

\subsection{Conclusion}

Although vacuum massage initially had been developed for the treatment of burn scars, literature reveals little evidence for the efficacy of this treatment. Very few studies investigated the effects of vacuum massage on human models with scars. The heterogeneous population and the wide diversity of study designs make it very hard to translate the previously mentioned results toward the burns and scars population in humans. Although the present study contributes additional evidence for the working mechanism of vacuum massage as an anti-scarring agent, the results should be confirmed by studies on human models. Variations in duration, amplitude, or frequency of the treatment have a substantial influence on collagen restructuring and reorientation, thus implying possible beneficial influences on the healing potential by mechanotransduction pathways. Vacuum massage may release the mechanical tension associated with scar retraction, and thus induce apoptosis of myofibroblasts. Suggestions for future research include upscaling the study design, investigating molecular pathways and dose dependency, comparing effects in different stages of repair, including evolutional parameters and the use of more objective assessment tools. 
흥

흥

产

플

54

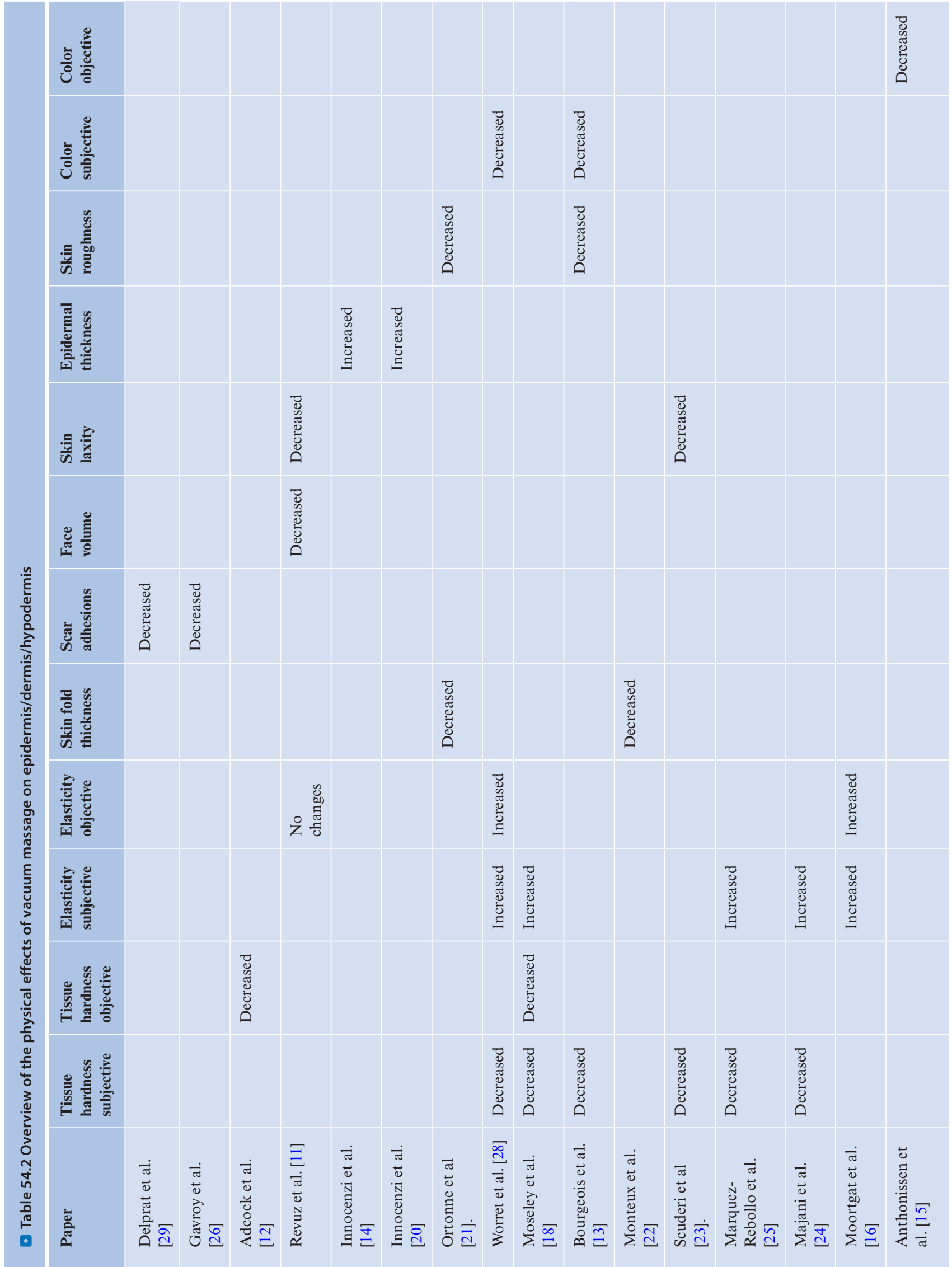




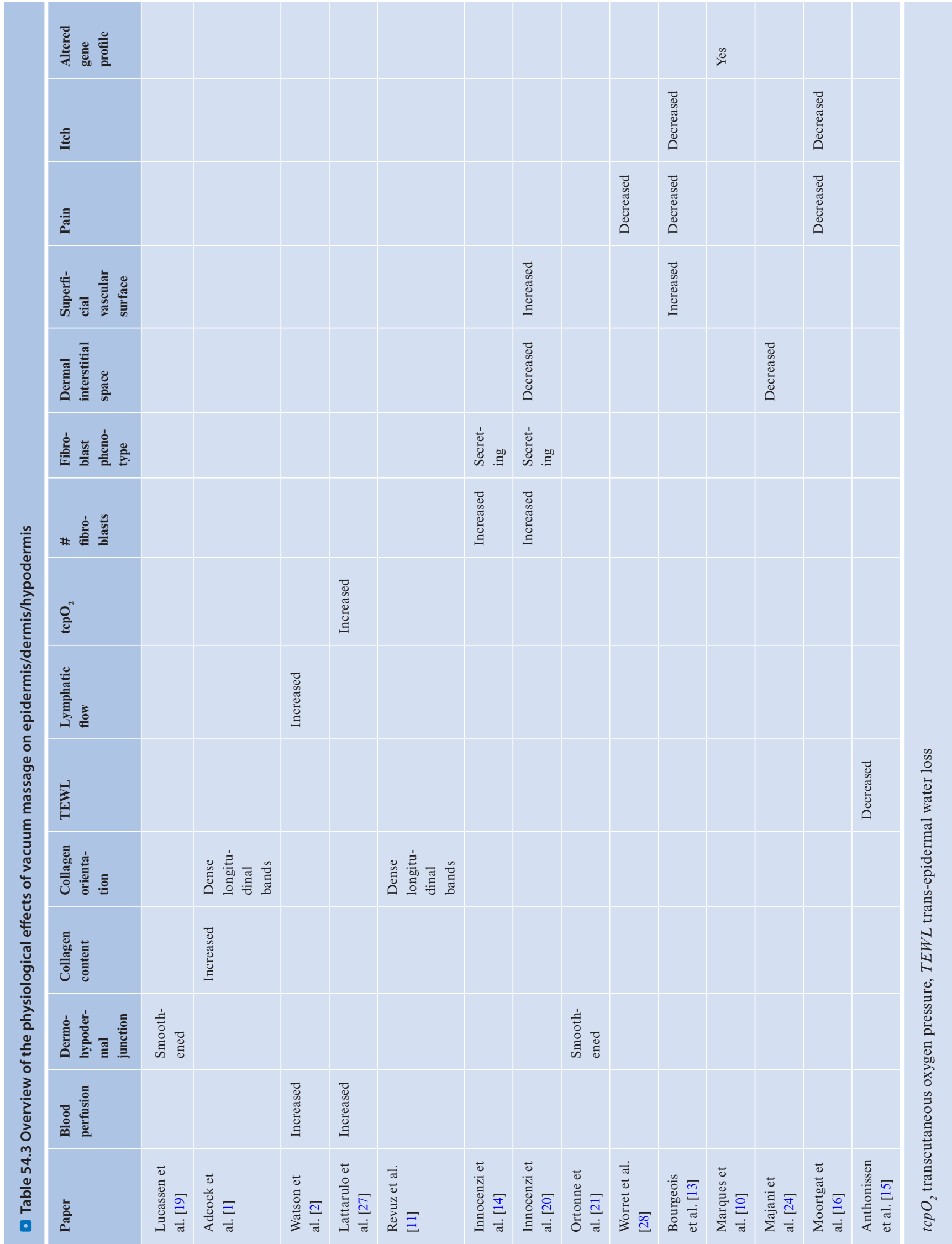




\section{Take-Home Messages}

- Vacuum massage is a way of standardizing massage techniques to optimize the treatment.

- Mechanotransduction is the presumed working mechanism behind vacuum massage.

- Improved tissue hardness and elasticity are the two most observed physical effects.

- The effect of vacuum massage is highly dependent on the type of maneuver performed.

- The more treatments are carried out, the higher the effect.

- Fibroblast migratory and proliferative capacities are enhanced by vacuum massage.

- Vacuum massage improves scar elasticity, which will probably lead to amelioration of function.

- Vacuum massage may release the mechanical stress associated with scar retraction.

\section{Bibliography}

1. Adcock D, Paulsen S, Davis S, Nanney L, Shack RB. Analysis of the cutaneous and systemic effects of Endermologie in the porcine model. Aesthet Surg J. 1998;18:414-20.

2. Watson J, Fodor P, Cutcliffe B. Physiological effects of Endermologie: a preliminary report. Aesth Surg. 1999;19:39-45.

3. Silver FH, Siperko LM, Seehra GP. Mechanobiology of force transduction in dermal tissue. Skin Res Technol. 2003;9:3-23.

4. Ingber DE. Cellular mechanotransduction: putting all the pieces together again. FASEB J. 2006;20:811-27.

5. Moortgat P, Maertens K. "The science of stretch": clinical implications of Mechanobiology of scars. Middle East Wounds Scar Meet. 2014.

6. Huang C, Holfeld J, Schaden W, Orgill D, Ogawa R. Mechanotherapy: revisiting physical therapy and recruiting mechanobiology for a new era in medicine. Trends Mol Med. 2013;19:555-64.

7. Verhaegen PDHM (2011) On burn scar reconstruction - clinimetric, experimental and clinical studies. ISBN: 978-90-5335413-1

8. Eckes B, Nischt R, Krieg T. Cell-matrix interactions in dermal repair and scarring. Fibrogenesis Tissue Repair. 2010;3:4.

9. Bouffard NA, Cutroneo KR, Badger GJ, White SL, Buttolph TR, Ehrlich HP, Stevens-Tuttle D, Langevin HM. Tissue stretch decreases soluble TGF-?? 1 and type-1 procollagen in mouse subcutaneous connective tissue: evidence from ex vivo and in vivo models. J Cell Physiol. 2008;214:389-95.

10. Marques M-A, Combes M, Roussel B, Vidal-Dupont L, Thalamas C, Lafontan M, Viguerie N. Impact of a mechanical massage on gene expression profile and lipid mobilization in female gluteofemoral adipose tissue. Obes Facts. 2011;4:121-9.

11. Revuz J, Adhoute H, Cesarini J, Poli F, Lacarrière C, Emiliozzi C. Clinical and histological effects of the lift device used on facial skin aging. Les Nouv Dermatologiques. 2002;21: 335-42.

12. Adcock D, Paulsen S, Jabour K, Davis S, Nanney LB, Shack RB. Analysis of the effects of deep mechanical massage in the porcine model. Plast Reconstr Surg. 2001;108:233-40.
13. Bourgeois JF, Gourgou S, Kramar A, Lagarde JM, Guillot B. A randomized, prospective study using the LPG technique in treating radiation-induced skin fibrosis: clinical and profilometric analysis. Skin Res Technol. 2008;14:71-6.

14. Innocenzi D, Balzani A, Panetta C. Modifications Morphologiques De La Peau Induites Par La Technique LPG ${ }^{\circledR}$. DERMOtime settembre 1-4. 2002.

15. Anthonissen M, Meirte J, Moortgat P, Maertens K, Daly D, Fieuws S, Lafaire C, De Cuyper L, Van den Kerckhove E. Influence on clinical parameters of depressomassage (part I): the effects of depressomassage on color and transepidermal water loss rate in burn scars: a pilot comparative controlled study. Burns. 2018;44:877-85.

16. Moortgat P, Lafaire C, Dom Y, Douws P, Van Tichelen J. The effect of prus depressomassage on elasticity and skin fold thickness of burn scars. Burns. 2011;37:S6-7.

17. Fanian F, Humbert P, Lihoreau T, Jeudy A, Elkhyat A, Robin S, Courderot-Masuyer C, Tauzin H, Lafforgue C, Haftek M. Mécano-stimulation of the skin improves sagging score and induces beneficial functional modification of the fibroblasts: clinical, biological, and histological evaluations. Clin Interv Aging. 2015;10:387.

18. Moseley A, Piller N, Douglass J, Esplin M. Comparison of the effectiveness of MLD and LPG technique ${ }^{\circledR}$. J Lymphoedema 2007;2:2-8.

19. Lucassen GW, Sluys WLN, Herk JJ, Nuijs AM, Wierenga PE, Barel AO, Lambrecht R. The effectiveness of massage treatment on cellulite as monitored by ultrasound imaging. Skin Research and Technology 1997;3(3):154-160

20. Innocenzi D, Balzani A, Montesi G, La Torre G, Tenna S, Scuderi $\mathrm{N}$, et al. Evidence des modifications cutanées induites par la technique LPG via une analyse d'images. DermoCosmetologia 2003:1-7.

21. Ortonne J-P. Treatment of cellulite. Nouv Dermatol 2002;22: 261-269.

22. Monteux C, Lafontan M. Use of the microdialysis technique to assess lipolytic responsiveness of femoral adipose tissue after 12 sessions of mechanical massage technique. Journal of the European Academy of Dermatology and Venereology 2008; 22(12): 1465-1470

23. Scuderi N. Randomized clinical trial on patient compliance and the ergonomics of two appliances for mechanical massage. 2008. http://www.icoone.pl/files/scuderi_eng.pdf. Accessed 30/09/2013.

24. Majani UGO, Majani A. Tissue mechanostimulation in the treatment of scars. Acta Medica Mediterr 2013;29:133-134.

25. Márquez-Rebollo C, Vergara-Carrasco L, Díaz-Navarro R, Rubio-Fernández D, Francoli-Martínez P, Sánchez-De la Rosa R. Benefit of Endermology on Indurations and Panniculitis/ Lipoatrophy During Relapsing-Remitting Multiple Sclerosis Long-Term Treatment with Glatiramer Acetate. Advances in Therapy 2014;31(8):904-914

26. Gavroy J.P., et al. LPG and the cutaneous softening of burns. J Plaies Cicatrices 1996;5:76-84.

27. Lattarulo P, Bacci PA, Mancini S. Physiological tissue changes after administration of micronized Diosmin / Hesperidin , individually or in association with Endermologie ${ }^{\circledR}$. Int $\mathbf{J}$ Aesthetic Cosmet Beauty Surg 2001;1:25-28.

28. Worret W-I, Jessberger B. Effectiveness of LPGR treatment in morphea. Journal of the European Academy of Dermatology and Venereology 2004;18(5):527-530

29. Delprat J, Ehrler S, Gavroy JP, Romain M, Thaury MN, Xenard J. Raideur et Tissus Mous. La Raideur Articul 1995:46-51. 
Open Access This chapter is licensed under the terms of the Creative Commons Attribution 4.0 International License (http://creativecommons. org/licenses/by/4.0/), which permits use, sharing, adaptation, distribution and reproduction in any medium or format, as long as you give appropriate credit to the original author(s) and the source, provide a link to the Creative Commons license and indicate if changes were made.

The images or other third party material in this chapter are included in the chapter's Creative Commons license, unless indicated otherwise in a credit line to the material. If material is not included in the chapter's Creative Commons license and your intended use is not permitted by statutory regulation or exceeds the permitted use, you will need to obtain permission directly from the copyright holder. 